\title{
Chemical Castration of the Sexual Offender versus Human Fundamental Rights and Freedoms
}

\author{
Andrada Nour* \\ Lecturer, Faculty of Law, Hyperion University, Bucharest, Romania
}

DOI: $10.36348 /$ sijlcj.2020.v03i05.002 $\quad$ | Received: 21.04 .2020 | Accepted: 01.05.2020 | Published: 07.04 .2020

*Corresponding author: Andrada Nour

\section{Abstract}

In order to prevent and discourage the commission of sexual offences, it is necessary to have certain special mechanisms able to combat the recidivism of those who have committed such acts, but even in such conditions it cannot be justified to limit the right of a person to physical integrity. In any system of law based on democratic principles, any party to a legal relationship, including when this is a state authority, has an obligation to adopt conduct that does not harm human dignity or the rights and freedoms of the citizens. Therefore, no democratic state can be recognized the right to draft laws contrary to or affecting the right of human beings to life and to physical and mental integrity. On the contrary, it is forbidden to apply, in any form, torture, cruel or inhuman or degrading treatment or punishment, even in the case of those persons who pose a danger and threat to society. Any attack on the dignity of the human being is impossible to accept in a democratic society. In this context, the question may arise as to whether or not this measure may be mandatory ordered by the court by a final judgment of conviction, irrespective of the main penalty applied and in the conditions in which it would be perform by specially authorized medical institutions.

Keywords: chemical castration, sexual offences, punishment, state of law, human rights, European Union.

Copyright @ 2020: This is an open-access article distributed under the terms of the Creative Commons Attribution license which permits unrestricted use, distribution, and reproduction in any medium for non-commercial use (NonCommercial, or CC-BY-NC) provided the original author and source are credited.

\section{INTRODUCTION}

Societies around the world have practiced castration for different reasons and in different forms, and in recent years, legislatures have perpetuated this practice but with a modern twist. Now, states use chemical injections to castrate their inmates [1], but the punitive characteristics of castration are what make a new law so controversial [2].

As a rule, security measures consist of certain medical or educational constraints and are applied in order to remove a danger or to prevent the commission of acts provided for by criminal law.

Sex offences are serious, direct and brutal violations of a person's sex life, affecting the person's mental freedom, bodily integrity, health, and even life. Rape is the most serious form in the category of these acts, especially when it is committed on a minor.

Some countries in the world have included in the category of safety measures that of chemical castration of persons who have committed acts of a criminal nature that threaten the sexual life of another person, whether the victim is an adult or a minor.
Given the extremely high degree of social danger of crimes that threaten the sexual life of the person, as well as the fact that very often victims of this category of crimes are children at a very young age, in the following we have proposed to examine whether the measure of chemical castration can be implemented as a mandatory criminal sanction in the domestic law of a democratic state without prejudice to fundamental human rights recognized and guaranteed by international documents.

In any rule of law, built on democratic principles, human dignity, fundamental rights and freedoms, the free development of the human personality are supreme values and must be respected. Each democratic state has both the obligation to recognize and guarantee to its citizens the right to life and to physical and mental integrity, as well as the obligation to respect and protect intimate and family life, respectively private life. Also, no one can and should not be subjected to torture or cruel, inhuman or degrading treatments or punishments. 
Based on these principles, no democratic country can adopt laws that would suppress or diminish the fundamental rights and freedoms of man and the citizen, and restricting the exercise of certain rights and freedoms, when necessary, must be done only according to the unanimously recognized rules of international law and proportional to the situation which led to this restriction, without prejudice to the very existence of the right or freedom. The constitutional provisions of any rule of law concerning human rights and freedoms must be interpreted and applied in accordance with the Universal Declaration of Human Rights, the covenants and other treaties to which that state is a party.

\section{RESEARCH METHODS}

This study is a legal approach to the issue of chemical castration of criminals who have committed crimes related to sexual life in terms of fundamental rights and freedoms of human beings recognized by international legal documents. The legal research that we have undertaken emphasizes the role of law in a democratic society by referring both to these international documents and to the jurisprudence of the European Court of Human Rights. The legal instruments presented are closely interdependent with the issues approached. They have been studied and explored to argue the views expressed in order to find a solution in accordance with respect for human rights. The legal material collected and used is part of scientific legal works, being subsequently interpreted in relation to the international legal instruments to which we refer.

\section{RESULTS AND DISCUSSION \\ The principle of the respect for human dignity and the prohibition of torture and other inhuman or degrading treatments or punishments \\ Recognition and guarantee of a person's right} to dignity is the essence of any rule of law based on democratic principles, in which regard there is a strong international concern for this right to be consecrated in reference documents, since the adoption in 1948 of the Universal Declaration of Human Rights, which states that "No one shall be subjected to torture or to cruel, inhuman or degrading treatments or punishments" (art. 5) and up to to the Rome Statute of the International Criminal Court[3], which in article 7 stipulates that torture committed "in the context of a widespread or systematic attack launched against of a civilian population and aware of this attack" is a crime against humanity. The same article 7 of the Statute of the Court defines torture as "the act of intentionally causing acute pain or suffering, physical or mental, to a person under the custody or control of the perpetrator", also stating that "the meaning of this term does not extend to pain or suffering resulting exclusively from legal sanctions, which are inherent in or occasioned by these sanctions".
Accordingly to article 3 (Prohibition of torture) of the European Convention for the Protection of Human Rights and Fundamental Freedoms[4] (hereinafter referred to as the "European Convention"), "No one shall be subjected to torture or to inhuman or degrading treatments or punishments." and accordingly to article 8 (Right to respect for private and family life) of the same document "Everyone has the right to respect for his private and family life, his domicile and his correspondence" and "Interference of a public authority in the exercise of this right is allowed only to the extent that this interference is provided for by law and if it constitutes a measure which, in a democratic society, is necessary for national security, public security, the economic well-being of the country, defense of order and prevention of criminal acts, protection of health or morals, or the protection of the rights and freedoms of others."

Also, the International Pact on Civil and Political Rights [5] provides in article 7 that "No one shall be subjected to torture or to cruel, inhuman or degrading treatments or punishments. Especially, it shall be prohibited for a person to be subjected to any medical or scientific experience without his or her consent." In article 10 it is stated that "Any person deprived of liberty shall be treated with humanity and with respect for the dignity that are inherent to the human person. The penitentiary system will include a treatment of convicts with the essential purpose of correcting them and reclassifying them socially. Young offenders will be separated from adults and subjected to a regime according to their age and legal status." At the same time, the document also expressly enshrines in article 17 that "No one shall be subjected to arbitrary or unlawful interference with his privacy, family, home or correspondence, or to unlawful attacks on his honor and reputation. Everyone has the right to the protection of the law against such interference or attacks."

The provisions of article 2 of the Convention against Torture and Other Cruel, Inhuman or Degrading Treatments or Punishments [6] are as follows: "Each State Party shall take effective legislative, administrative, judicial and other measures to prevent acts of torture in its territory. No exceptional circumstances, whatever it would be, state of war or threat of war, internal political instability or any other state of emergency, may not be invoked to justify torture."

The jurisprudence of the European Court of Human Rights (ECHR) also reflects the fact that respect for the dignity and freedom of the human being is the foundation of the European Convention for the Protection of Human Rights and Fundamental Freedoms. The prohibition provided in article 3 of the European Convention is of an absolute nature, and no exception or derogation can be possible, even if an 
emergency of public interest occurs in the sense of endangering the life of the nation. The ECHR judgments in Selmouni v. France (July 28, 1999), Assenov and Others v. Bulgaria (October 28, 1998) and Peers v. Greece (April 19, 2001) are relevant in this regard.

We note that, unlike the Rome Statute of the International Criminal Court, which defines the notion of torture, the European Convention nowhere defines the notions contained in Article 3. These have been defined by the European Court by jurisprudence way. Thus, in the opinion of the Court, in order to be included in the provisions of article 3 of the European Convention, an inhuman or degrading treatment must reach a minimum level of severity, and because this level is closely interdependent with all the circumstances of the case, including duration, physical and mental effects, age and health of the victim, its assessment becomes relative. The Court found it inhuman either a premeditated treatment applied for a long period, treatment results in injury or at least physical or moral suffering, or a treatment which generated anxiety, fear or feelings of inferiority likely to humiliate the person concerned and to affect their moral or physical endurance [7]. Even if the others do not consider the respective treatment as humiliating or degrading, for the incidence of article 3 , it is sufficient that the person concerned considers himself humiliated [8].

We must specify that, in it, any punishment of a judicial nature, no matter how severe it may be, presupposes a form of humiliation, but this does not mean that it falls under the incidence of article 3 of the European Convention, respectively that it can be considered as "degrading". In support of our assertion, we invoke even article 3 of the European Convention, which distinguishes between a simple judicial punishment and an inhuman and degrading one, since it makes express reference to the prohibition of only the latter. Therefore, in our opinion, a harsh punishment can be interpreted within the meaning of article 3 of the European Convention, only in the context of the existence of exceptional circumstances, especially since the states have a great freedom of judgment regarding the penalties applicable to offenders.

The question of whether a punishment is cruel and unusual should depend on whether people who were fully informed as to the purposes of the punishment and its potential drawbacks would find the penalty unacceptable on the whole. While there are good justifications for this idea, it too is criticized on the grounds that judges are allowed to substitute their own opinions of what people should think for what they actually do think, and therefore are acting in an antidemocratic manner [9].
From the jurisprudence of the European Court we observe that, in no form, a prohibited behavior can be a motivation by the behavior of the victim [10] and that even when fighting against very serious phenomena, such as terrorism or organized crime, torture or inhuman or degrading punishments are strictly prohibited by the European Convention and beyond.

Consequently, in our opinion, regardless of the gravity of a deed, the criminal policy of all democratic states must be in full accordance with the provisions of article 3 of the European Convention, namely to be against the application of any sanctions involving acts of torture and other inhuman or degrading treatments or punishments, even when it could be said that such sanctions would have preventive effects.

We believe that the criminal policy of any democratic state must not contravene the fundamental rights and freedoms of human beings, respect and protection of human dignity, his physical and mental integrity can not be affected by the inclusion in legislation of such a sanctioning system regardless of the nature and gravity of the act committed.

\section{Intervention in the health field}

At the global level, a number of documents have been adopted regarding the minimum standards necessary to be met when applying a medical treatment. Article 2 (the Primacy of the Human Beings) of the European Convention for the Protection of Human Rights and Dignity of the Human Being with regard to the Applications of Biology and Medicine[11] states that "The interests and well-being of human beings must prevail over the unique interest of the society or science.", and article 5 establishes the "General Rule" according to which "An intervention in the field of health can be done only after the person in question has given his or her free and informed consent. This person receives in advance adequate information regarding the purpose and nature of the intervention, as well as regarding the consequences and risks. The person in question may at any time freely withdraw his or her consent."

We consider that no derogation can be made from the rule that any human being is autonomous and independent in making his or her own decisions about his or her health, which is why, without exception; no medical treatment can be applied without the person's consent, freely expressed in advance. In accordance with the rights granted to any patient, no medical intervention, except for emergency life-saving interventions when the patient is unable to express his will, may be performed without the informed consent of the person concerned. In the practice of the European Court it has been highlighted that even when in the absence of the application of a medical treatment, the result would be fatal for the patient, however he cannot 
be forced to accept it. The European Court has ruled that the application of medical treatment following the refusal or lack of consent in the case of an adult patient and in full mental faculties constitutes a violation of his right to physical integrity [12]. The Court also stated that a measure deemed to be a therapeutic necessity cannot be considered degrading or inhuman [13]. Also, in the case of the convicted person being in detention, if a medical intervention was performed against the will of the person, even if it is about a therapeutic necessity, the Court held that both the medical necessity and the existence and observance of procedural guarantees for such judgment must be convincingly demonstrated [14].

Consequently, we express the opinion that any safety measure consisting in a medical treatment, can be applied only with the freely expressed consent of that person, based on a medical opinion, without having serious consequences on the person and, at the same time, with respecting the procedural guarantees necessary for such a decision.

\section{The measure of chemical castration in the national law of the states}

From a medical point of view, chemical castration falls into the category of medical treatments that involve the administration of drugs whose action is antiandrogenic, in order to reduce a person's libido to inhibit sexual impulses.

"Today, chemical castration is used in many states, whether as a punishment or as a medical treatment for sex offenders, mainly for the perpetrators of sexual crimes against children. Chemical Castration is a part of criminal legislations in many states including USA, Argentina, Australia, Estonia, Israel, Moldavia, New Zealand, Poland, Russia, Denmark, Germany, Hungary, France, Norway, Finland, Iceland, Lithuania, United Kingdom, Belgium, Sweden, Macedonia, Turkey, Indonesia etc[15].”

"These states have all realized that more than just imprisonment is necessary to keep a sex offender from re-offending, and most of them realize that chemical castration is the most proper means to achieve that end [16]"'.

At the European level, the measure of chemical castration can be applied either during the execution of a custodial sentence, or as a requirement for conditional release before serving the full sentence of imprisonment, or as an alternative to imprisonment. Usually, chemical castration is applied only voluntarily, completing psychotherapy, and after the convict has been subjected to a psychiatric examination.
Of these states, at European level, only in Poland is it mandatory to apply this measure, a measure regulated by a law that was adopted on November 5, 2009 and entered into force on June 8, 2010. In accordance with the provisions of that law, the perpetrator of an act of rape of a minor under the age of 15 may be forced to undergo chemical and psychological therapy. The court may order medical treatment, regardless of the will of the offender, based on the opinions of a sexologist and of a two doctors.

Although the European Committee for the Prevention of Torture and Inhuman or Degrading Treatments or Punishments criticized these provisions in the Report made following its visit to Poland from 26 November to 8 December 2009, recommending a review of the legislation, the Committee found that the measure was not in principle contrary to the European Convention for the Prevention of Torture and Inhuman or Degrading Treatments or Punishments, if, of course, certain conditions are met so as not to be circumscribed to inhuman and degrading treatment. The Committee stated that the measure of chemical castration should be purely voluntary, based on the written, freely expressed and informed consent of the person, following an individual medical and psychiatric assessment, with the possibility of the convict withdrawing his consent at any time. At the same time, the Committee indicated that the person concerned should be explained in detail, in writing, the purpose of the treatment, the adverse effects, and the consequences that would affect him in the event of refusal. The Committee also recommended that the application of medical treatment to be accompanied by psychotherapy or other forms of psychological counseling, in order to minimize as much as possible the risk of recidivism of the offender, highlighting that the measure of chemical castration should not be a general condition for release from prison, but should be applied only to certain persons on the basis of individual assessments.

\section{SOLUTIONS AND CONCLUSIONS}

It is true that, starting from the danger posed by sexual offences, all states are obliged to develop an efficient legislation which, through the penalties applied, would discourage committing such acts. Although punishments are equally forms of state coercion, as well as means of correcting and reeducating the offender, applied in order to restore order and social equity, to prevent further crimes and to correct the offender, it is still unacceptable that the execution of the punishment to cause physically suffering or to affect the dignity of the convicted person.

In a state of law, based on fair, efficient and democratic criminal justice, all legislation must recognize and guarantee the respect for the dignity of the person throughout the criminal process, including during the execution of the sentence. 
As we said before, although chemical castration, in the case of sexual offences, is provided in the criminal legislation of several states, however, with the exception of Poland, in all these European countries the measure is voluntary, not mandatory, it is accompanied by psychotherapy and it is applied under the condition of subjecting to a psychiatric examination. Having important consequences on the person's health, we consider it necessary, prior to the application of treatment, to perform a medical expertise for therapeutic eligibility which should take into account the duration and the opportunity of this drug therapy, and after starting treatment the person to benefit for psychotherapy and the health status to be monitored. Free and valid consent must be obtained before starting treatment, and no form of coercion must be used to obtain it. The inclusion criteria, the exclusion criteria for such treatment and the treatment procedure must be complete and set out in detail. The detainee must be regularly examined before, during and after the cessation of the treatment by an independent medical authority.

Therefore, chemical castration should be ordered by the court only after medical advice and only if doctors recommend the application of the measure.

In our opinion, by the mandatory application of chemical castration of the convicted person, in the absence of full and informed of the consent of this person, in the absence of medical assessment of the need to apply this therapy, in the absence of subsequent psychotherapy and monitoring of the person's health, on the one hand, the guarantees of respect for human dignity are affected, the fundamental right of the person to physical and mental integrity is restricted - essential principles of any democratic rule of law, and on the other hand, it is violated article 3 of the European Convention for the Protection of Human Rights and fundamental freedoms and also articles 2 and 5 of the Convention for the Protection of Human Rights and Dignity of the Human Being with regard to the Applications of Biology and Medicine.

\section{REFERENCES}

1. Oswald, Z. E. (2013). "Off with His_": Analyzing the Sex Disparity in Chemical Castration Sentences. Michigan Journal of Gender \& Law,
19(2),
472.
Available
on

http//repository.law.umich.edu/mjgl/vol19/iss2/5

2. Stelzer, G.L. (1997). Chemical Castration and the Right to Generate Ideas: Does the First Amendment Protect the Fantasies of Convicted Pedophiles. Minnesota Law Review. 1339. Available on http://scholarship.law.umn.edu/mlr/1339

3. Done at Rome on 17 July 1998. Published in the Official Gazette number 211 of 28 March 2002.

4. Done at Rome on 4 November 1950 and amended by a series of additional protocols to this Convention.

5. Adopted at New York on December 16, 1966.

6. Adopted at New York on December 10, 1984.

7. See ECHR judgments in Price v. The United Kingdom, Mouisel v. France or Naumenko v. Ukraine.

8. See the ECHR judgment in Tyrer.(1978). The United Kingdom of April 25.

9. Lombardo, R. A. (1997). California's Unconstitutional Punishment for Heinous Crimes: Chemical Castration of Sexual Offenders. 65 Fordham Law Reviews 2611. Available on https://ir.lawnet.fordham.edu/flr/vol65/iss6/8

10. See the ECHR judgment in Labita v. Italy of April 6, 2000.

11. Done at Oviedo at April 4, 1997.

12. See the Judgments of the ECHR in Pretty v. The United Kingdom (April 29, 2002), Glass v. The United Kingdom (March 9, 2004).

13. See the ECHR judgment in Herczegfalvy v. Austria (September 24, 1992).

14. See the ECHR judgment in Nevmerzhitsky v. Ukraine (April 5, 2005).

15. Ratkoceri, V. (2017). Chemical Castration of Child Molesters - Right or Wrong?!. European Journal of Social Sciences Education and Research, 11(1), 70$76 . \quad$ Available on http://journals.euser.org/files/articles/ejser_sep_dec _17_nr_1/Vedije.pdf

16. Tullio, E. M. (2010). Chemical Castration for Child Predators: Practical, Effective, and Constitutional. Chapman Law Review. 13:191, 191-220. Available on https://www.chapman.edu/law/_files/publications/ CLR-13-elizabeth-tullio.pdf 